Nordic Journal of Modern Language Methodology

\title{
What counts as "knowledge" in foreign language teaching and learning practices today?
} Foreign language pedagogy as a mirror of its time

\author{
av Ulrika Tornberg
}

\begin{abstract}
When situating the probably most influential transnational steering instrument for language teaching and learning in Europe today, i.e., The Common European Framework of Reference for Languages: Teaching, Learning and Assessment (CEFR) (2001) in the context of the contemporary discussion at both national and transnational levels about various standardardised, internationally comparable tests of learners' achievements and about increasing demands on schools and teachers to deliver internationally comparable results, at least some suggestions may be made. The discourse of "knowledge", as expressed in the $C E F R$, is described by means of a taxonomy of decontextualised "competences" and "skills", and categorised in specific decontextualised domains and reference levels. What counts as "knowledge" in foreign language education seems to be what can be efficiently tested. In this sense the CEFR functions a as a mirror of its time. Taking a brief retrospect of the history of foreign language teaching and learning as a point of departure, the purpose of this text is to discuss some didactic consequences of the contemporary focus on "competences" and "skills" as expressed in the $C E F R$, for the aims and meaning of foreign language education in an increasingly heterogeneous and plurilingual world.
\end{abstract}

Key words: Communication, Interaction, Knowledge, Competences, Selective Tradition, Fields of Tension, CEFR

\section{Introduction}

That foreign language pedagogy mirrors its time means on one hand that curricular texts not only express predominant ideas of what language teaching and learning ought to be about at a certain point in history. On the other hand they also articulate more general conceptions of knowledge prevalent in the society where the curricular texts have been constructed. However, since curricular texts are the result of various compromises between the views of different curricular writers, they may also express alternative views of the aims and objectives of foreign language pedagogy, as well as a selective tradition with historical roots, according to which teaching and learning practices are constructed in the way they have "always" been constructed, and where, so to say, old traits get new functions (cf. Englund 1986/2005, Tornberg, 2000, 2007, 2009). Although the choice of teaching and learning content at a certain point in time may be seen as value-laden, offering specific emphases and 
priorities as to what should be taught and learnt, alternative views are always present, leading to the emergence of various fields of tension.

What counts as "knowledge" in foreign language pedagogy, then, depends on whom you ask, and at what time in history you ask, since foreign languages have played different roles in (Western) societies at different times, implying different ideas of what language education should aim at. During the Middle Ages, for example, when Latin functioned as a lingua franca across cultural and linguistic boundaries, the focus was on language use. During the Enlightenment and for centuries to come, the analytical and descriptive study of Latin (and Greek) took over as a university discipline and became one of the means, at least as was believed, to achieve formal Bildung (Titone 1968; Kelly 1969; Rivers 1970).

The practice of teaching and learning different national languages was first developed in relation to trade. Later, when some of these national languages - German, French and English - were introduced as subjects at universities, the teaching of these so-called modern languages was adapted to the teaching of Latin and Greek, i.e., to the well-known focus on grammatic analysis and translation (Kelly 1969). Although some efforts were made at the end of the 19th century to shift the prevalent focus on form to a focus on language use (Viëtor 1882), the linguistic preconditions of spoken language among language teachers at that time, as well as a lack of political interest for international plurilingual communication, kept the grammartranslation method on track for another 50 years (Tornberg 2009, 2011).

The paradigmatic shift to a new emphasis on spoken language and language function did not occur until after the end of the Second World War. It took place more or less simultaneously in two very different contexts: in the audiolingual language teaching context then predominant in the USA, and in the communicative approach to language teaching and learning introduced by the Council of Europe in Strasbourg (ibid).

\section{The communicative turn - and fields of tension}

After the war, a large group of American soldiers were sent to Europe on different political missions where they would have to communicate in several European languages. Their need to develop spoken language skills coincided with the behavioristic, audiolingual theory of language learning under development at that time in the United States (Ellis 1990). On the basis of a structuralist language description, spoken phrases with built-in unanalysed, grammatical structures were supposed to be learnt by language drills and then readily used in communication. Furthermore, not having to analyse grammar was thought of as a help for those learners who were not used to grammatical abstractions, and, consequently, as a democratic means to facilitate language learning for all. This was at least one of the arguments used in the process of reforming the Swedish school system in a democratic direction during the 1950s and 1960s (SOU 1948:27). 
However, at about the time when the audiolingual language learning theory dominated in the USA - as well as in Sweden - a different development was initiated by a subdivision of the Council of Europe in Strasbourg, Conceil de la coopération culturelle (CDCC). The Council of Europe was founded in 1949 against the background of the devastation and genocide of the Second World War, and with the aim to promote freedom, democracy and communication across national boundaries. In a way, the medieval idea about the benefits of cross-national, cross-cultural communication was revived, albeit under modern, post-war conditions. The CDCC, starting in 1962, made foreign language learning a central part of the peace project. The original idea was that if the people in Europe were able to talk to each other, further wars might be prevented (Modern Languages (1971-1981, p 3).

By the motto of The Communicative Approach to Language Teaching and Learning, teacher training, in-service training conferences and research programmes were organised all over Europe, and the functional, communicative aspects of language were heavily stressed by a number of scientific publications (Austin 1962; Piepho 1974; Wilkins 1977).

Nevertheless, at the same time as a clear aim was expresed by the CDCC to include political, social, personal and even emancipatory aspects of language education in the programme, there was, from the very start, another ambition involved as well, i.e., to develop an internationally shared, effective rationale for language objectives, assessment and evaluation. This early field of tension within the CDCC may be grasped in the quotations below:

The fundamental change from 'what'? to 'how?' entails a shift from an objective, structural perspective to a subjective, functional perspective (...) Furthermore, language learning can no longer be treated as a purely technical matter, treatable in isolation from social, cultural and political aspects of education. At every point, issues are raised concerning the relations of the individual and the community: the nature of authority; the relation between teacher and learner; the status of the citizen (Project No 12, 1988, p 21).

There is a distinct idea expressed in the above quotation about language as a personal tool for action and interaction in a social, cultural and political context. The shift from "what" to "how" also indicates that the objectives, i.e., what communication should be about, ought to be decided by those who communicate, i.e., teachers and language learners - and not top down and in advance. The text also emphasises that there must be a break with earlier practices, although it is not clear how this should be done. The essence of the quotation below is quite different:

The Council of Europe wanted to try to construct language courses where the total content was broken down into smaller 'units'. Each such unit would represent a clearly defined learning objective which 
would be formed in such a way that it could be evaluated and tested in an objective manner. In this way each unit could be assigned a certain merit (...). As each unit was directed towards a specific learning objective there would also be an internal relationship between the different units. The various units thus formed different parts of a more 'total' system (Malmberg, 1989, p 13).

Obviously, two very different conceptions of "knowledge" are expressed in the two quotations. Doll (1993) makes an interesting distinction between teaching in an open and a closed educational system. Whereas the open system invites new perspectives and new knowledge to emerge in interaction by those who take part, the closed system aims at bringing about strictly defined objective criteria of knowledge. It may be argued, then, that the field of tension within the language learning programme of the CDCC expresses a conflict between an open and a closed educational system, similar to the system that Doll (1993) describes..

One possible explanation for the tension between the two quotations above, as between other texts from those early years (Modern Languages 1971-1981), may be that although the intentions of the CDCC were interactive, democratic, emancipatory and peace-promoting, the models for building this "new" communicative language learning programme were extremely traditional, i.e., expressing a selective tradition in curriculum construction. Consequently, as in Tyler's famous Basic Principles of Curriculum and Instruction (1949), everything was categorised and classified in detail. All the competences and skills that the European learners were supposed to develop, all the domains where these competences were expected to be necessary, and all the situations in which the learners might need to use the language in the future, were listed and explained (van Ek, 1975). Van Ek's The Threshold Level (1975) was the first attempt of the CDCC to construct a comprehensive language teaching and learning taxonomy. It addressed adult learners of English specifically, but other publications in other languages followed (cf. Baldegger, Müller \& Schneider: Kontaktschwelle Deutsch als Fremdsprache (1980).

For about two decades, though, the democratic, interactive and personal focus on communication in language teaching and learning practices prevailed, for example in a publication from 1983, Across the Threshold Towards Multilingual Europe, where the communicative aspects of peace, mutual understanding and human rights were once more stressed. And in Sheils (1988), Communication in the Modern Languages Classroom, plenty of communicative tasks, like writing poems, topics for discussion and role play, were suggested. Teachers were even supposed to ask themselves questions about their democratic partnership behaviour, such as the following:

-do students dare to express unconventional ideas and opinions in the classroom? 
-does the teacher support them in expressing their own ideas and tolerate them?

-do the students listen to each other and tolerate others' ideas?

-does the teacher take into account the individual personalities

of the students?

-do teacher and students together try to make use of their different experiences and ideas?(Sheils, 1988, p 3).

The first traces in Sweden of the influence of the CDCC were visible in the curriculum of the 1980s, Lgr 80, where the communicative approach was expressed as a list of language functions to be learnt and used. It became even more visible, however, in the curricular texts for languages (2000), where one of the aims for the learner was to develop the interactive competence "to express her/his own thoughts and opinions in the language and to understand the thoughts and experiences of others" (SKOLFS 2000:135, p 16). The CDCC and its communicative goals were even mentioned in the introductory text to the curriculum.

\section{Other times - other tensions...}

In the course of time, however, the focus on mutual understanding, personal, communicative action and democracy has weakened as the work of the CDCC after 1975 has gradually moved towards an emphasis on the importance of effective educational goals. The aim has also been to change the behaviour of learners, and, more specifically, to define what they should be able to accomplish after the learning process is completed (van Ek, 1986).

The contemporary form of educational governance by goals and results expressed to a certain extent already in the documents of the CDCC, has also, in a more general sense, developed gradually during the last two decades, in Sweden as well as transnationally (Lundahl \& Waldow 2009; Englund; Forsberg \& Sundberg (2012). As mentioned above, the internationalisation of educational policies has led to recurring assessments of knowledge, a practice supposed to enable the participating countries to make their results more comparable and efficient. This, in turn, has led to certain pedagogical consequences, such as valuing a specific form of "central knowledge", because it is easily tested (Berggren (2012). According to Forsberg (2012) another consequence has been a tendency to decontextualise "knowledge", which may be traced back to the development of the Key Competences" of the OECD (2005), which in turn, has led to an increasing amount of tests that are externally initiated.

So, when the goals are decided top down, the tests are externally initiated and the responsibility of the teacher has changed from being professional to being accountable (Solbrecke \& Englund 2011), the space for teacher interpretation and decision is reduced (Lundahl \& Waldow, 2009). In the Swedish curriculum (2011), the development towards 
governance by results is more or less completed, leaving the politically defined "standards" in the centre of the curriculum (Englund 2012). "Knowledge" today is what can be tested (ibid.).

In The common European Framework of Reference for Languages: Learning, Teaching, Assessment (CEFR) (2001), the governing function dominates. The "What?" has reached a leading position over the "How?". And since the CEFR has now been translated into 40 languages, into Swedish by Skolverket (the National Board of Education) (2009), it is probably also having an impact on language teaching and learning -and testing - practices all over Europe. In the commentaries to the Swedish language syllabus for English and other modern languages (2011), the dependence on the CEFR for its objectives, reference levels and standards is clearly expressed (Skolverket /The National Board of Education 2011, pp 6-7).

The $C E F R$ presents itself as "comprehensive":

This means simply that you should find in it all you need to describe your objectives, methods and products. The scheme of parameters, categories and examples explained in Chapter 2 (most compactly in the boxed text at the beginning)and presented in some detail in Chapters 4 and 5 is intended to give a clear picture of the competences (knowledge, skills, attitudes) which language users build up in the course of their experience of language use and which enable them to meet the challenges of communication across language and cultural boundaries (i. e. to carry out communicative tasks and activities in the various contexts of social life with their conditions and constraints). The common reference levels introduced in Chapter 3 offer a means to map progress as learners build up their proficiency across the parameters of the descriptive scheme (CEFR, 2001, p xii).

Indeed, the above text will help to illustrate the complexity of the document, where handling this complexity of human language means that you will have to break "language competence down into separate components" (ibid, p 1). The problem is, however, how this is done. If, for example, you break down the concept of "competence" into "general competences", such as declarative knowledge, sociocultural knowledge, intercultural awareness, and even existential competence, including your motivations, cognitive style and personality factors, as dichotomised, for example, in "rigidity/flexibility", "industry/laziness", etc. (CEFR, pp 101-106) - how will all this help you in your teaching and learning practices? Are you supposed to take these competences into account when teaching, testing and grading? For instance, is existential competence supposed to be connected with the different aspects of "communicative competence"? There is a passage that may indicate that it is, although the recommendation is modified by saying that it is up to the teacher and the learners to decide about it: 
In an intercultural approach, it is a central objective of language education to promote the favourable development of the learner's whole personality and sense of identity in response to the enriching experience of otherness in language and culture (CEFR, 2001, p 1).

In spite of the modification noted, it is possible to interpret the quotation as a recomendation to include the fostering of the learner and her/his personality in the teaching practices. Does this mean that the teacher should be in charge of the personal deleopment of the student? Somewhat pradoxically, it may be argued that the comprehensiveness of the CEFR leads to a closure, rather than to a variety of possibilities.

There is another problem with all the "Whats" in the list of competences. Although the competences are described as domain specific, no real context is mentioned for any of them. Even sociocultural knowledge is described in a vacuum, since the features listed are supposed to be characteristic of "a particular European society and its culture" (CEFR, p 102). But in the internationalised, globalised and heterogeneous world that surrounds us today, such a European society will be hard to find (cf. Tornberg, 2012). In connection with the different domains mentioned in the CEFR, it will also be hard to decide
(...) which themes learners will need/be equipped/be required to handle in the selected domains;
which sub-themes they will handle with respect to each theme;
which specific notions relating to locations, institutions/organisations, persons, objects, events and operations they will need/be equipped
/be required to handle in order to deal with each (sub)theme (CEFR, p 53).

The influence of the earlier document, The Threshold Level (1975), is quite clear. As for the future language needs of the learners, including their lifelong learning, the scope of this needs analysis leaves but little space for the unexpected to happen (cf. Doll 1993).

The question, then, is: what is the purpose of the CEFR? According to the introduction, it provides "a common basis for the elaboration of language syllabuses, curriculum guidelines, examinations, textbooks, etc., across Europe" (p 1). It also describes what language learners have to learn in order to use language for communication. It defines levels of proficiency and provides the means for educational administrators, course designers, etc., to co-ordinate their educational efforts (ibid). In this sense it functions as a real taxonomy, like Tyler's rationale (1949), mentioned earlier, and seems to fit in well with the contemporary need to define measurable educational standards.

However, the former, alternative perspective of the saims and meaning of foreign language eduction is still discernable as in the quotation below: 
(...) it is only through a better knowledge of European modern languages that it will be possible to facilitate communication and interaction among Europeans of different mother tongues in order to promote European mobility, mutual understanding and co-operation, and overcome prejudice and discrimination (...) (CEFR, 2001, p 2).

Obviously, the old field of tension expressed in the earlier work of the Council of Europe between the "What?" and the "How?" remains: on the one hand, its democratic, interactive and emancipatory visions; on the other, the taxonomic drive.

\section{Conclusion}

The purpose of this text has been to discuss som possible didactic consequences for foreign language pedagogy that the contemporary focus on "competences" and "skills" as expressed in the CEFR may lead to. According to the original vision of the Council of Europe the ability to communicate with other people with different languages and cultures would lead to a mutual understanding between European citizens - and to democracy, empowering the individual as well. Consequently, the functional, interactive aspects of language were stressed, and the discussions about the aims and meaning of foreign language teaching and learning were quite vivid.

The question was how to realise this vision. The solution to use old traits but with new functions implied a field of tension within the CDCC, between wanting to concentrate on the "How?" and, at the same time, needing the "What?". In the course of time and within the general, transnational context of measurable "knowledge" and of international comparisons of learners' achievements, the "What?" has taken over most of the CEFR. This, in turn, has had a profound impact on, for example, the Swedish curricular texts for languages in the curriculum of 2011.

However, the old field of tension between the "What?" and the "How?" still exists in the $C E F R$, albeit with a bias in favour of the "What?". Nevertheless, this also makes it possible to interpret the space left for teachers and learners initiatives to use it for their own discussions about what may be the content of language learning today. It leaves a possibility to, at least partly, choose another way of dealing with communication than according to the lists of competences and reference levels in the CEFR. The field of tension, then, present in the $C E F R$, offers a certain amount of freedom, which may later even lead to a new focus on interactive communication across national and cultural boundaries in Europe. Against the background of the increasing xenophobia and intolerance in many European countries today, a new peace movement may soon be needed. 


\section{References:}

Austin, J. (1982): How To Do Things With Words. New York: Oxford University Press.

Across the Threshold towards Multilingual Europe - Vivre le multilinguisme européen (1983): Strasbourg: Council of Europe.

Baldegger, M.; Müller, M.\& Schneider, G. (1981): Kontaktschwelle Deutsch als Fremdsprache. München: Langenscheidt.

Berggren, J. (2012): En gemensam resa eller skilda resor. Talet om kärnämnen i gymnasieskolan 1990-2009. Utbildning \& Demokrati nr 2, 2012, s 39 -61. (A travel in common or separate travels - policy texts on core subjects in the Swedish upper secondary school 1990 to 2009. Education \& Democracy No 2, 2012, pp 39-61).

Common European Framework fo Reference for Languages: Learning, teaching, assessment (2001): Modern Languages Division, Strasbourg: Cambridge University Press.

Doll, W. E. (1993): A Post-Modern Perspective on Curriculum. Advances in Contemporary Educational Thought, Vol. 9. New York and London: Teachers College, Columbia University.

Ellis, R. (1990): Instructed Second Language Acquisition. Oxford: Oxford University Press.

Englund, T. (2012): Utbildningspolitisk monopolism - nya utmaningar för läroplansteorin. T. Englund; E. Forsberg \& D. Sundberg (red): Vad räknas som kunskap? Läroplansteoretiska utsikter och inblickar i lärarutbildning och skola. Stockholm: Liber. s 20-38. (Monopolism of educational politics - new challenges for curriculum theory. T. Englund; E. Forsberg \& D. Sundberg, eds: What counts as Knowledge? Views and insights of curriculum theory into teacher education and schools. Stockholm: Liber. pp 20-38).

Englund, T; Forsberg, E \& Sundberg, D. (2012): red, Vad räknas som kunskap? Läroplansteoretiska utsikter och inblickar I lärarutbildning och skola. Stockholm: Liber.( T. Englund; E. Forsberg \& D. Sundberg, eds: What counts as knowledge? Views and insights of curriculum theory into teacher education and schools. Stockholm:Liber).

Forsberg, E. (2012): kunskapssyn i omvandling? T. Englund; E. Forsberg \& D. Sundberg (red): Vad räknas som kunskap? Läroplansteoretiska utsikter och inblickar i lärarutbildning och skola. Stockholm: Liber, s 225-242. ( A change in the discourse of knowledge? T. Englund; E. Forsberg \& D Sundberg, eds: What counts as knowledge ? Views and insights of curriculum theory into teacher education ans schools. Pp 225 to 242. 
Kelly, R. (1969): 25 Centuries of Language Teaching. Rowley Mass: Newbury House.

Kommentarmaterial till kursplanen i moderna språk (2011): Skolverket. Stockholm: Fritzes. (Comments on the curriculum of modern languages, 2011, National Agency for Education. Stockholm: Fritzes).

Läroplan för grundskolan (Lgr 80): Skolöverstyrelsen. Stockholm: Liber Utbildningsförlaget. (Curriculum for the compulsory school, Lgr 80. National Board of Education. Stockholm: Liber Utbildningsförlaget).

Läroplan för grundskolan, förskoleklassen och fritidshemmet (2011): Skolverket. Stockholm: Fritzes. ( Curriculum for the compulsory school, preschool class and the leisure-time centre 2011. National Agency for Education. Stockholm: Fritzes).

Lundahl, C. \& Waldow, F. (2009): Standardisation and 'quick languages': the shape-shifting of standardised measurement of pupil achievement in Sweden and Germany. Comparative Education. Vol. 45, No. 3. pp 365-385.

Malmberg, P (1989): Towards a Better Language Teaching - a presentation of the Council of Europe's language projects. Uppsala University/In-Service Training Department.

Modern Languages (1971-1981): Strasbourg: Council of Europe.

OECD (2005): The Definition and Selection of Key Competences. Executive Summary.

Piepho, H-E. (1974): Kommunikative Kompetenz als übergeordnetes Lernziel im Englischunterricht. Dornburg-Frickhofen: Frankonius Verlag.

Project No. 12: Learning and Teaching Modern Languages for Communication (1988): Strasbourg: Council of Europe

Rivers, W. M. (1970): Teaching Foreign Language Skills. Chicago: The University of Chicago Press.

Sheils, J.(1988): Communication in the Modern Language Classroom. Strasbourg: Council of Europe.

Skolverkets föreskrifter (SKOLFS 2000): Moderna språk i grundskolan. 
(Directions of the National Agency for Education, 2000, Modern languages in the compulsory school).

Skolverket (2009): Gemensam europeisk referensram för språk: lärande, undervisning och bedömning. Stockholm: Fritzes.

Solbrecke,T. D. \& Englund, T. (2011): Bringing professional responsibily back in. Studies in Higher Education (Published on-line).

SOU 1948: 27. 1946 års skolkommissions betänkande med förslag till riktlinjer för det svenska skolväsendets utveckling. Stockholm: Ecklesiastikdepartementet. (The Public State Commissions 1948:27. The report of the School Commission concerning suggestions for the development of the Swedish educational system).

Titone, R. (1968): Foreign Languages: A Historical Sketch. Washington D. C: Georgetown University Press.

Tornberg, U. (2000): Om språkundervisning I mellanrummet - och talet om "kommuniktion" och "kultur” I kursplaner och läromedel från 1962 till 2000. Acta Universitatis Upsaliensis, Uppsala Studies in Education 92. (On Foreign Language Teaching and Learning in a Discursive Space - and conceptions of "communication" and "culture" in curricular texts and teaching materials from 1962 to 2000. Uppsala Studies in Education 92).

Tornberg, U. (2009): Språkdidaktik. Malmö: Gleerups. (Language Didactics. Malmö: Gleerups).

Tornberg, U. (2011): Språket som form eller funktion - ett återkommande vägval för språkundervisningen. B. Bucht (red): Vägval i skolans historia. Tidskrift från Föreningen för svensk undervisningshistoria, årgång 11, $n r$ 2. s 16-19.(Language as form or functionrecurring cross-roads in language pedagogy. B. Bucht, ed: Cross-roads in the History of Schools. The Association of the Swedish History of Education. Vol 11, No 2. pp 16-19).

Tornberg, U. (2012): Die unerträgliche Leichtigkeit des Kulturbegriffs, von einem undeutlichen Objekt des Wissens in der Fremsprachenpädagogik. Bildung in Deutschland, dem Baltikum und Schweden gestern und heute. Universität Magdeburg/Uppsala Universität. s 40- 46. (The unbearable lightness of "culture" - on a blurred object of knowledge in foreign language pedagogy. "Bildung" in Germany, the Baltic States and Sweden yesterday and today. University of Magdeburg/Uppsala University. pp 40-46).

Tyler, R. (1949): Basic Principles of Curriculum and Instruction. Chicago: The University of Chicago Press. 
Van Ek, J. A. ( 1975): The Threshold Level. Strasbourg: Council of Europe.

Van Ek, J. A. (1986): Objectives for Foreign Language Learning. Strasbourg: Council of Europe.

Wilkins, D.A. ((1977): Notional Syllabuses. Oxford: Oxford University Press.

Viëtor, W.(1882): Der Sprachunterricht muss umkehren. A. Howatt (1984): A History of English Language Teaching. Oxford: Oxford University Press. 